\title{
Penerapan Media Jquiz pada Pembelajaran Menyimak Karya Sastra di IKIP Budi Utomo Malang
}

\author{
$\operatorname{Artifa~Sorraya~}^{(1)}$, Yunita Anas Sriwulandari ${ }^{(2)}$ \\ ${ }^{12}$ IKIP Budi Utomo Malang, Indonesia
}

Email: 1arrtiefa.soerraya@gmail.com, ${ }^{2}$ cikyun2906@gmail.com,

\begin{tabular}{l}
\hline Tersedia Online di \\
\hline http://www.jurnal.unublitar.ac.id/i \\
ndex.php/briliant \\
\hline \\
\hline Sejarah Artikel \\
\hline Diterima pada 20 September 2019 \\
Disetujui pada 15 November 2019 \\
Dipublikasikan pada 30 \\
November 2019 Hal. 415-423 \\
\hline
\end{tabular}

\section{Kata Kunci:}

Media JQuiz, Pembelajaran, Menyimak, Karya Sastra

\section{DOI:}

http://dx.doi.org/10.28926/briliant. v3i4.365

\begin{abstract}
Abstrak: Proses kegiatan pembelajaran diperlukan model, metode, strategi, dan media pembelajaran, untuk tercapainya kegiatan belajar mengajar. Media JQuiz adalah salah satu media yang dapat diterapkan pada kegiatan pembelajaran. Media JQuiz merupakan media untuk membuat berbagai macam jenis soal, salah satunya soal pada matakuliah menyimak. Menyimak dilakukan secara sengaja untuk mendapatkan informasi dari penutur. Tujuan dalam penelitian ini, antara lain: 1) mendeskripsikan hasil kemampuan menyimak mahasiswa pada pembelajaran menyimak karya sastra pada prates), 2) mendeskripsikan hasil kemampuan mahasiswa pada pembelajaran menyimak karya sastra pada postes, dan 3) mendeskripsikan perbedaan kemampuan menyimak mahasiswa pada pembelajaran menyimak karya sastra antara prates dan postes. Penelitian ini menggunakan rancangan eksperimen satu kelompok atau berpasangan, karean hanya
\end{abstract} menggunakan satu sampel saja. Teknis analisis data menggunakan uji t statistik, uji validitas satu sampel. Hasil uji t statistik $=4,861>\mathrm{t}$ - tabel $=2$, 093, maka terdapat perbedaan antara X1 dan X2. Dari hasil tersebut membuktikan bahwa ada perbedaan kemampuan menyimak antara prates dan postes, yang tanpa menerapkan media JQuiz dan dengan menerapkan media JQuiz pada pembelajaran menyimak karya sastra.

\section{PENDAHULUAN}

Pembelajaran adalah proses kegiatan, metode, dan teknik yang membuat seseorang atau makhluk hidup yang ingin belajar. Definisi sebelumnya menjelaskan bahwa seseorang dapat mengetahui perbedaan atau perubahan yang dialami tetapi tidak proses kegiatan pembelajaran itu (Ghazali, 2013:155). Pembelajaran adalah proses interaksi dan komunikasi peserta didik, atau pembelajar dengan pendidik dan sumber belajar. Pembelajaran merupakan kegiatan untuk memberikan arahan, bantuan dan motivasi, yang diberikan pendidik agar terjadi proses pemerolehan ilmu dan pengetahuan serta pembentukan sikap. Pembelajaran adalah proses kegiatan untuk membantu peserta didik agar dapat belajar dan melaksanakan kegiatan belajar dengan baik. Pembelajaran yang efektif sangat bergantung dari dorongan pelajar atau peserta didik dan kreativitas pengajar atau pendidik. Target belajar atau indicator dapat diukur melalui perubahan sikap dan hasil kemampuan peserta didik, melalui proses kegiatan belajar. Desain pembelajaran dan pola 
pembelajaran yang baik ditunjang fasilitas yang memadai ditambah dengan kreativitas guru akan membuat peserta didik lebih mudah mencapai target atau indikator belajar (Abidin, 2012:144).

Media JQuiz merupakan salah satu dari bagian media Hot Potatoes media Hot Potatoes sendiri merupakan media untuk membuat berbagai macam jenis soal. Mulai dari pilihan ganda, soal esay, soal campuran, dan bahkan soal dalam bentuk teka-teki silang yang dapat menarik dalam hal pengembangan evaluasi pembelajaran. JQuiz merupakan bagian dari Hot Potatoes atau anak dari media Hot Potatoes yang termasuk jenis soal yang pilihan ganda. JQuiz terdapat berbagai soal jenis pilihan ganda, soal isian singkat, soal pilihan ganda majemuk atau soal pilihan jawaban lebih dari satu, dan gabungan antara soal isian singkat dan pilihan ganda.

Menyimak adalah proses komunikasi, mendengarkan secara baik, dan keseluruhan dengan penuh perhatian secara menyeluruh, yang diucapkan oleh penutur atau pembicara. Menyimak merupakan langkah atau proses kegiatan mendengarkan lambang-lambang bunyi lisan dengan penuh seksama, pemahaman, apresiasi, serta interpretasi untuk mendapatkan informasi, menangkap isi, serta memahami makna komunikasi yang tidak disampaikan oleh si pembicara melalui ujaran atau Bahasa lisan, tahap terakhir memberikan respon baik secara tuturan, ataupun tertulis, (Tarigan, 2008:153). Menyimak dilakukan secara sengaja untuk mendapatkan informasi dari penutur pembiacara yang dibutuhkan oleh penyimak. Keterampilan menyimak yang baik menyangkut sikap, ingatan, persepsi atau interpretasi kemampuan membedakan, inteligensi, dan perhatian. Menyimak efektif merupakan dasar kemampuan berbicara yang sangat penting dan juga merupakan pondasi dalam keberhasilan kemampuan, membaca dan menulis (Ghazali, 2013:170).

\section{Model Pembelajaran Keterampilan Berbahasa}

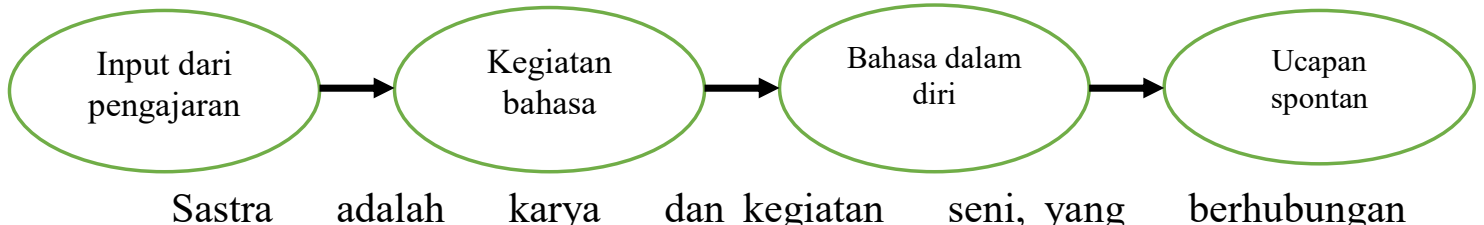

dengan ekspresi penciptaan. Sastra adalah ungkapan secara tiba-tiba atau mendadak dari perasaan batin yang paling mendalam. Sastra adalah ungkapan tertulis atau lisan diri manusia, yang biasa berupa pengalaman yang dialami pikiran, perasaan, ide atau pendapat, semangat, keyakinan dalam bentuk gambaran fakta atau kongkrit yang membangkitkan keinginan atau daya tarik dengan bantuan Bahasa (Tabrani, 2001:4). Karya sastra adalah seni indah menarik dan memenuhi kebutuhan manusia terhadap naluri atau keinginan keindahannya. Kebutuhan terhadap keindahan atau kesenangan, merupakan kodrat manusia sebagai makhluk hidup. Seni pada umunya dan sastra umumnya dan sastra pada khusunya adalah karya kebudayaan yang diciptakan oleh manusia dan diperlukan oleh manusia yang sudah mufakat akan hal sastra tersebut. Kebutuhan manusia yang bersifat jasmaniah dipenuhi oleh ilmu pengetahuan, teknologi, dan ekonomi. Kebutuhan spiritualnya dipenuhi agama dan seni. Sastra merupakan bagian dari seni.Studi sastra dibagi menjadi dua yaitu sastra serius dan sastra hiburan Sastra serius untuk merangsang pembaca untuk lebih berpikir dan merenungkan hal-hal atau bahasa yang digunakan dalam karya sastra tersebut. 
Karya sastra hiburan lebih memiliki tujuan, untuk meneyenangkan dan banyak disenangi karena menggunakan gaya bahasa yang ringan dan sederhana. Berbeda dengan karya sastra serius pemilihan kata atau diksinya sangat berat (Darma, 2019:4).

Puisi adalah bentuk karya sastra yang menggunakan kata-kata yang indah dan kaya makna. Dicirikan dengan pembahasan yang padat namun indah, biasanya karya diungkapkan puisi secara tidak langsung, dapat menimbulkan kecenderungan dari seseorang untuk menguasai kesadaranya, melalui bahasa yang memiliki ritme dan makna khusus. Contoh dari puisi yaitu seperti sajak, pantun, balada. Unsur fisik puisi diantaranya: 1) diksi, yaitu kata yang dipilih atau ditulis seorang penyair atau penulis dalam menciptakan hasil karyanya. Kata-kata tersebut tentu kata yang mengungkapkan keindahan dan perasaan, 2) Pengimajian, merupakan kata atau susunan kata yang dapat mengungkapkan pengalaman indrawi, 3) majas atau gaya bahasa, yaitu bahasa kias yang dapat meningkatkan efek dan menimbulkan konotasi tertentu, 4) ritme, yaitu persamaan bunyi pada puisi baik di awal, tengah, maupun akhir baris puisi, 5) kata konkret yaitu kata yang dapat ditangkap dengan indra, memungkinkan munculnya imaji, 6) tipografi merupakan perwajahan dari puisi (Samosir, 2013:20-24).

Peneliti menentukan pembelajaran matakuliah menyimak karena peneliti sebagai dosen pengampu matakuliah tersebut. Peneliti tidak memilih semua pada pembelajaran karya sastra, tetapi hanya pada menyimak pembacaan puisi, karena puisi bagian atau genre dari karya sastra selain prosa dan drama. Mahasiswa diminta untuk menyimak pembacaan puisi kemudian menganalisis dari segi unsur fisik dan batin. Dari pemaparan tersebut peneliti menentukan tiga tujuan penelitian yang akan di deskripsikan pada pembahasan selanjutnya, tujuan penelitian tersebut, yaitu antara lain: 1) mendeskripsikan hasil kemampuan menyimak mahasiswa pada pembelajaran menyimak karya sastra sebelum menerapkan media JQuiz (prates), 2) mendeskripsikan hasil kemampuan mahasiswa pada pembelajaran menyimak karya sastra sesudah menerapkan media JQuiz (postes), dan 3) mendeskripsikan perbedaan kemampuan menyimak mahasiswa pada pembelajaran menyimak karya sastra sebelum (prates) dan sesudah (postes) menerapkan media JQuiz. Peneliti ingin mengetahui apakah penerapan media JQuiz sangat efektif pada pembelajaran menyimak karya sastra.

Asumsi atau anggapan dasar merupakan kebenaran umum tentang pokokpokok permasalahan yang sedang diteliti. Arikunto (2010:104) berpendapat bahwa "anggaran dasar" adalah sesuatu yang diyakini kebenarannya oleh peneliti yang akan berfungsi sebagai hal-hal yang akan dipakai untuk tempat berpijak bagi peneliti dalam melaksanakan penelitiannya". Menurut Winarso Surakhmad anggapan dasar atau postulat adalah sebuah titik tolak pemikiran yang kebenarannya diterima oleh penyelidik (Arikunto, 2010:105). Penelitian ini didasarkan oleh sejumlah asumsi sebagai berikut (1) mahasiswa Prodi Pendidikan Bahasa dan Sastra Indonesia angakatan 2018 semester 2 dapat menerapkan media JQuiz pada pembelajaran karya sastra dengan baik, (2) penerapan media JQuiz pada berperan penting dalam pencapaian pembelajaran pembelajaran menyimak karya sastra, dan (3) hasil pembelajaran menyimak dengan menerapkan media JQuiz lebih bagus dari pada tidak menerapkan media JQuiz. 


\section{METODE}

Rancangan atau desain penelitian adalah rencana struktur penelitian yang disusun sesuai sistematika sehingga peneliti dapat memperoleh jawaban dari permasalahan-permasalahan penelitian. Rencana itu merupakan susunan mulai awal hingga akhir secara menyeluruh yang mencakup program penelitian yang ingin dikerjakan oleh peneliti (Setyosari, 2013:175). Penelitian ini menggunakan rancangan satu kelompok atau berpasangan dengan pratespascates. Rancangan ini hanya melibatkan satu kelompok. Rancangan penelitian ini dapat digambarkan sebgaai berikut.

$$
\mathrm{O} 1 \quad \mathrm{X} \quad \mathrm{O} 2
$$

Rancangan penelitian one group pretest-postest ini menurut Gall, Gall \& Borg (2003) meliputi tiga langkah, yaitu: (1) pelaksanaan prates, atau pra tindakan untuk mengukur variabel terikat, (2) pelaksaan perlakuan, tindakan, atau eksperimen, dan (3) pelaksanaan pascates, sesudah tindakan untuk mengukur hasil, dampak terhadap variabel terikat. Dengan demikian dampak perlakuan ditentukan dengan cara membandingkan skor hasil prates dan pascates. Penelitian pendidikan dan kurikulum seperti halnya penelitianpenelitian bidang lainnya ditujukan untuk memeperoleh simpulan tentang kelompok yang besar dalam lingkup wilayah yang luas, tetapi hanya dengan meneliti sekelompok kecil dalam daerah yang lebih sempit. Kelompok besar tersebut, bisa terdiri atas seperti orang, siswa, kepala sekolah, dsb, atau lembaga seperti sekolah, jurusan, fakultas, kantor, dinas, direktorat, dsb: organisasi seperti komite sekolah, dewan sekolah, organisasi guru, organisasi profesi, dsb: atau bisa juga benda-benda seperti bangunan sekolah, fasilitas belajar, media belajar, bukubuku, dll. Lingkup wilayah bisa mencangkup seluruh wilayah negara, satu provinsi ataupun satu kota atau kabupaten. Kelompok besar dan wilayah yang menjadi lingkup penelitian kita disebut populasi (Sukmadinata, 2011:250). Penelitian tindakan kelas merupakan penelitian yang ditujukan untuk mencermati atau meneliti suatu kegiatan berupa sebuah tindakan yang bertujuan untuk memperbaiki dan meningkatkan kualitas pembelajaran secara berkelanjutan (Muslich, 2011:11).

Generalisasi dari sampel ke populasi itu jelas mengandung risiko tinggi yaitu akan terdapat kekeliruan atau tidak tepat. Makin tidak sama sampel dengan populasinya, makin besar kemungkinan kekeliruan itu. Oleh sebab itu, teknik penentuan sampel menjadi sangat penting perannya dalam penelitian. Berbagai teknik sampel itu pada hakikatnya adalah cara-cara untuk memperkecil kekeliruan generalisasi dari sampel ke populasi. Hal ini bisa dicapai manakala diperoleh sampel yang representative yaitu sampel yang benarbenar mecerminkan populasinya. Istilah populasi merujuk pada keseluruhan kelompok dari mana sampel-sampel itu diambil (Setyosari, 2013:197).

Populasi pada penelitian ini adalah mahasiswa IKIP Budi Utomo Malang, sedangkan sampelnya adalah mahasiswa prodi Pendidikan Bahasa dan Sastra Indonesia angkatan 2018 semester 2 di IKIP Budi Utomo Malang. Peneliti menentukan sampel tersebut karena peneliti menjadi dosen pengampu pada prodi tersebut. Penentuan sampel peneliti menggunakan teknik sampel random atau acak. Instrumen adalah alat yang digunakan untuk megumpulkan data (Arikunto, 2010:265). Peneliti menjaring data dengan 
satu macam instrument berupa tes. Tes adalah serentetan pertanyaan atau latihan atau alat lain yang digunakan untuk mengukur keterampilan pengetahuan, intelegensi, kemampuan atau bakat yang dimiliki oleh individu atau kelompok (Wahyuni, 2008:13). Instrumen tes ini digunakan untuk mengetahui dan mengukur hasil kemampuan kegiatan menyimak, sebelum dan sesudah diterapkannya JQuiz, dalam pembelajaran menyimak karya sastra. Validitas tes mengarah pada ketepatan interpretasi hasil penggunaan, suatu prosedur evaluasi sesuai dengan tujuan pengukurannya.

Validitas merupakan suatu keadaan apabila instrumen evaluasi (misalnya tes) dapat mengukur yang nyata harus diukur secara tepat (Wahyuni 2008). Suatu tes hasil belajar dikatakan valid apabila tes tersebut benar-benar mengukur hasil belajar bahasa. Validitas tidak semata-mata berkaitan dengan kedudukan tes sebagai alat melainkan terutama pada kesesuaian hasilnya, sesuai dengan tujuan penyelenggarakan tes. Berdasarkan instrumen penelitian tersebut validitas yang digunakan adalah validitas ukuran yang menunjuk pada pengertian seberapa jauh mahasiswa yang sudah menerapkan dalam bidang bahasa yang menunjukkan kemampuan yang lebih tinggi daripada yang belum menerapkan. Menguji validitas ukuran adalah dengan mengujikan sebuah tes pada subjek yang sama pada waktu yang berbeda.

Tes pertama dilakukan sebelum mahasiswa diberi pelajaran yang diteskan itu (pretes) dan kedua setelah mahasiswa selesai diajar pelajaran itu (postes). Signifikasi perbedaan nilai rata-rata siswa antara pretes dan postes itulah yang diuji dengan teknik t-tes. Teknik analisis data dalam penelitian ini adalah menggunakan validitas ukuran. Perbedaan nilai rata-rata dari hasil kemampuan menyimak sebelum menerapkan media JQuiz dan sesudah menerapkan media JQuiz diuji dengan tekhnik t-tes untuk mengetahui signifikansi perbedaan nilai rata-rata tersebut. Berikut ini untuk menguji validitas berpasangan atau satu sampel.

$$
\mathrm{t}=\frac{D}{\sqrt{N(N-1)}}
$$

$\mathrm{D}=$ mean selisih antara skor pertama dan skor kedua pada sampel

$$
D=\frac{D D}{N}
$$

$\mathrm{d}=$ selisih skor pertama dengan skor kedua

$$
\mathrm{d}=\Sigma D-\frac{(\Sigma D)^{2}}{N}
$$

\section{HASIL}

Hasil penelitian ini untuk menjawab atau berkorelasi pada rumusan atau fokus masalah, rumusan masalah sudah dijabarkan pada pendahuluan. Rumusan masalah tersebut antara lain: 1) bagaimana hasil kemampuan menyimak mahasiswa pada pembelajaran menyimak karya sastra sebelum menerapkan media JQuiz (prates)?, 2) bagaimana hasil kemampuan mahasiswa pada pembelajaran menyimak karya sastra sesudah menerapkan media JQuiz (postes)?, dan 3) bagaimana perbedaan kemampuan menyimak mahasiswa pada pembelajaran menyimak karya sastra sebelum (prates) dan sesudah (postes) menerapkan media JQuiz? 
Hasil kemampuan menyimak mahasiswa pada pembelajaran menyimak karya sastra sebelum menerapkan media JQuiz mendapatkan jumlah skor 1569, jumlah mahasiswa sebagai sampel 20 mahasiswa, untuk mendapatkan nilai ratarata tersebut yaitu:

$$
=\frac{\text { jumlah kesehuruhan skor }}{\text { jumlah mahasiswa }}=\frac{1569}{20}=78,45
$$

Jadi, rata-rata atau mean dari hasil kemampuan mahasiswa pada pembelajaran menyimak karya sastra sebelum menerapkan media JQuiz adalah 78,45.

Hasil kemampuan menyimak mahasiswa pada pembelajaran menyimak karya sastra sesudah menerapkan media JQuiz mendapatkan jumlah skor 1604, jumlah mahasiswa sebagai sampel 20 mahasiswa, sama seperti pengambilan prates. Nilai rata-rata tersebut,

$$
=\frac{\text { jumlah keseluruhan skor }}{\text { jumhah makasiswa }}=\frac{\mathbf{1 6 0 4}}{\mathbf{2 0}}=80,2
$$

Jadi, rata-rata atau mean dari hasil kemampuan mehasiswa pada pembelajaran menyimak karya sastra sesudah menerapkan media JQuiz adalah 80,2.

Perbedaan kemampuan hasil menyimak mahasiswa pada pembelajaran menyimak karya sastra antara sebelum (prates) dan ssudah (postes) menerapkan media JQuiz dapat dianalisis menggunakan uji $\mathrm{t}$ statistik, yaitu uji validitas dengan sampel yang sama atau berpasangan. Analisis datanya sebagai berikut. Penyelesaian:

1) Taraf signifikansi $\mathrm{a}=0,05$

Tes dua ekor

$\mathrm{Db}=\mathrm{N}-1,20-1=19$

$\mathrm{t}$ kritis menurut tabel $\mathrm{t}$ dengan $\mathrm{a}=0,05$, tes dua ekor, $\mathrm{db}=19$ adalah 2,093

2) Kriterium

Jika t sattistik $\geq 2,093$ atau $t$ statistik $\leq-2,093$, maka terdapat perbedaan yang signifikan antara X1 dan X2

$$
\begin{aligned}
& \mathrm{D}=\frac{\sum D}{N}=\frac{35}{20}=1,75 \\
& \mathrm{D}=\sum \mathrm{D}^{2}-\frac{\left(\sum D\right)^{2}}{N}=111-\frac{(35)^{2}}{20}=111-\frac{1125}{20}=111-61,25=49,75 \\
& \mathrm{t}=\frac{D}{\sqrt{M(N-1)}} \\
& \mathrm{t}=\frac{1,75}{\sqrt{\frac{49,75}{20(20-1)}}} \\
& \mathrm{t}=\frac{1,75}{\sqrt{49,75}} \\
& \mathrm{t}=\frac{1,75}{\sqrt{49,75}}
\end{aligned}
$$




$$
\begin{aligned}
& t=\frac{1,75}{\sqrt{0,130}} \\
& t=\frac{1,75}{0,360}=4,861
\end{aligned}
$$

\begin{tabular}{|c|c|c|c|c|c|c|}
\hline No & NPM & NAMA & PRETES & POSTES & $\mathrm{D}$ & $\mathrm{D}^{2}$ \\
\hline 1 & 2181000310001 & M. NUR AZIZ & 80 & 81 & 1 & 1 \\
\hline 2 & 2181000310034 & FALERI DESI & 70 & 75 & 5 & 25 \\
\hline 3 & 2181000310016 & ALIVIA YANANDRA & 75 & 75 & 0 & 0 \\
\hline 4 & 2181000310054 & ERNIS AYU & 76 & 75 & -1 & 1 \\
\hline 5 & 2181000310032 & TASYA SANA & 72 & 74 & 2 & 4 \\
\hline 6 & 2181000310031 & MIFTAKHUL UMMAH & 76 & 76 & 0 & 0 \\
\hline 7 & 2181000310011 & EDWIN & 85 & 87 & 2 & 4 \\
\hline 8 & 2181000310021 & GRACE DEBORA & 77 & 78 & 1 & 1 \\
\hline 9 & 2181000310015 & MARIA MAGDALENA & 75 & 76 & 1 & 1 \\
\hline 10 & 2181000310064 & YANA & 86 & 88 & 2 & 4 \\
\hline 11 & 2181000310024 & MUQODDAM & 86 & 87 & 1 & 1 \\
\hline 12 & 2181000310018 & M. FAJAR & 72 & 73 & 1 & 1 \\
\hline 13 & 2181000310012 & KARINA & 74 & 76 & 2 & 4 \\
\hline 14 & 2181000310019 & DWI WIDI & 80 & 82 & 2 & 4 \\
\hline 15 & 2181000310048 & SHINTA & 80 & 82 & 2 & 4 \\
\hline 16 & 2181000310032 & YANUARI MELANIA & 85 & 86 & 1 & 1 \\
\hline 17 & 2181000310066 & PETRUS PATI BOKOL & 70 & 71 & 1 & 1 \\
\hline 18 & 2181000310018 & WASTI MERE & 85 & 87 & 2 & 4 \\
\hline 19 & 2181000310010 & AURELIA SIRKEN & 80 & 85 & 5 & 25 \\
\hline 20 & 2181000310017 & VERONIKA ENIWATI & 85 & 90 & 5 & 25 \\
\hline \multicolumn{3}{|c|}{ JUMLAH } & 1569 & 1604 & 35 & 111 \\
\hline \multicolumn{3}{|c|}{ MEAN } & 78,45 & 80,2 & & \\
\hline
\end{tabular}

3) Data Mahasiswa Angkatan 2018

4) Keputusan:

Karena harga $\mathrm{t}$ statistik $=4,861>\mathrm{t}$ - tabel $=2$, 093, maka terdapat perbedaan yang signifikan antara X1 dan X2.

5) Interpretasi:

Ada perebdaan yang signifikan antara hasil prates dan postes. Jadi, tes tersebut memiliki validitas ukuran.

Dari hasil analisis tersebut bahwa ada perbedaan antara hasil prates yang memiliki rata-rata 78,45 dan hasil postes memiliki rata-rata 80,2, itu menunjukkan bahwa penerapan JQuiz sangat efektif diterapkan pada pembelajaran menyimak karya sastra, tepatnya materi menyimak puisi.

\section{PEMBAHASAN}

Penelitian ini dilakukan untuk mengetahui apakah penerapan media JQuiz pada pembelajaran menyimak karya sastra di IKIP Budi Utomo Malang khususnya menyimak pemabacaan puisi sangat efektif diterapkan pada pembelajaran tersebut, untuk mahasiswa IKIP Budi Utomo Malang, Prodi Pendidikan Bahasa dan Sastra Indonesia khususnya angkatan semester 2. Peneliti memilih menerapkan pembelajaran tersebut karena angkatan 2018 sedang menempuh matakuliah menyimak karya sastra, dan peneliti sebagai dosen pengampuh matakuliah tersebut. Peneliti tidak menjadikan semua angkatan 2018 
sebagai sampel penelitian karena jumlah yang terlalu banyak. Peneliti hanya menentukan sampel dari populasi sebanyak 20 sampel dipilih secara acak atau random. Mahasiswa melakukan kegiatan pembelajaran menyimak pembacaan puisi secara langsung yang dibacakan oleh dosen pengampuh, sebelum dibacakan puisi, mahasiswa sudah terlebih dahulu hal apa saja yang perlu disimak untuk menjawab pertanyaan.

Kegiatan proses pembelajaran tersebut sebagai tes, hasilnya untuk menentukan hasil dari tes tersebut efektif atau tidak. Dilihat dari rumusan masalah, terdapat tiga rumusan masalah, pembahasan ini untuk membahas dari hasil penelitian yang sudah dijelaskan pada sub bab sebelumnya. Pertama hasil kemampuan menyimak karya sastra khususnya menyimak pembacaan puisi secara langsung sebelum menerapkan media JQuiz dapat dihitung dari jumlah hasil kemampuan menyimak mahasiswa secara meneyeluruh dibagi jumlah sampel atau mahasiswa, dari hasil hitungannya diperoleh rata-rata 78,45. Dari hasil tersebut sebenarnya sudah sesuai KKM (Kriteria Kelulusan Minimal). Pengambilan hasil tes selanjutnya menggunakan atau menerapkan media JQuiz. Mahasiswa mencatat hal-hal penting dalam pembacaan puisi yang dibacakan, misalnya judul, tema, topik, amanat, dll. Dari segi instrinsik maupun ekstrinsik, setelah itu ada soal dalam media JQuiz, sepertinya biasa tetapi ini media ini menyenangkan karena sepertinya bermain sambil berpikir, mengingat hal-hal apa saja yang sudah dibacakan dalam puisi tersebut. Hasil rata-rata diperoleh 80,25 untuk pengukuran sama dengan hasil sebelumnya. Selanjutnya untuk pengukuran mengetahui perbedaan kemampuan menyimak pembacaan puisi antara sebelum dan sesudah menggunakan uji t-statistik. Dari hasil pengukuran tersebut mendapatkan hasil 4,861, dan hasil itu lebih besar dati t-tabel 2,093. Hasil pengukuran tersebut membuktikan bahwa ada perbedaan antara menerapkan media JQuiz dan tidak menerapkan media JQuiz, berarti media JQuiz sangat efektif diterapkan pada pembelajaran menyimak khsususnya menyimak pembacaan puisi. Mahasiswa merasa senang mengikuti proses kegiatan pembelajaran tersebut.

\section{KESIMPULAN}

Hasil kemampuan menyimak pada pembelajaran menyimak karya sastra khususnya pada menyimak pembacaan puisi, untuk nilai prates mendapatkan nilai rata-rata atau mean 78,45 . Hasil kemampuan menyimak pada pembelajaran menyimak karya sastra khusunya pada menyimak pembacaan puisi, untuk nilai postes, yang sama dengan prates mendapatkan nilai rata-rata atau mean 80,2. Perbedaan antara nilai prates yang tanpa perlakuan tidak menerapkan media JQuiz dengan nilai postes dengan perlakuan menerapkan media JQuiz menggunakan uji $\mathrm{t}$ statistic validitas berpasangan atau satu sampel. Dari hasil analisis tersebut bahwa ada perbedaan yang signifikan antara hasil prates yang memiliki rata-rata 78,45 dan hasil postes memiliki rata-rata 80,2, itu menunjukkan bahwa penerapan JQuiz sangat efektif diterapkan pada pembelajaran menyimak karya sastra, tepatnya materi menyimak puisi.

\section{SARAN}

Saran dari peneliti untuk peneliti selanjutnya lebih kreatif lagi dan lebih mendalami tentang media dalam pembelajaran kegiatan proses menyimak. Saran 
berikutnya ditujukan pada mahasiswa untuk lebih berkonsentrasi lagi dalam proses kegiatan menyimak, karena masih banyak faktor-faktor yang memengaruhi kegagalan dalam pembelajaran menyimak dari faktor eksternal maupun internal.

\section{DAFTAR RUJUKAN}

Abidin, Yunus. (2012). Pembelajaran Bahasa Berbasis Pendidikan Karakter.Bandung: Refika Aditama.

Arikunto, Suharsimi. (2010). Prosedur Penelitian Suatu Pendekatan Praktik. Jakarta: PT Rineka Cipta.

Darma, Budi. (2019). Pengantar Teori Sastra. Jakarta: PT Kompas Media Nusantara.

Ghazali, Syukur. (2013). Pembelajaran Ketrampilan Berbahasa Dengan Pendekatan Komunikatif-Interaktif. Malang: PT Refika Aditama.

Muslich, (2011). Mengenal Penelitian Tindakan Kelas. Jakarta: Indeks.

Samosir, Tiorida. (2013). Apresiasi Puisi. Bandung: Yrama Widya

Setyosari, Punaji. (2013). Metode Penelitian Pendidikan dan Pengembangan. Jakarta: Kencana Prenada Media Group.

Sukmadinata, Syaodih. (2011). Metode Penelitian Pendidikan. Bandung: PT Remaja Rosdakarya.

Tarigan, Guntur. (2008). Menyimak Sebagai Keterampilan Berbahasa. Bandung: Angkasa Bandung.

Tabarani, Ahmad. (2001). Teori Sastra. Malang: Modul Matakuliah Pendidikan Bahasa dan Sastra Indonesia Universitas Islam Malang."

Wahyuni, Sri. (2008). Evaluasi Pembelajaran Bahasa. Malang: Universitas Islam Malang. 